\title{
NOTE
}

\section{EFFECT OF SOME SYNTHETIC PEPTIDES ON THE ALPHA-TOXIN PRODUCTION BY CLOSTRIDIUM PERFRINGENS PB6K}

Jn a previous paper, it was shown that a certain fraction derived from a peptone was effective in promoting the growth and alpha-toxin production by $\mathrm{Cl}$. perfringens PB6K (Murata et al., $1958 \mathrm{~b}$ ). However, isolation and identification of the active principle(s) have not yet been successful, although it was suggested that substances of peptide nature might be responsible for this activity. In 1959, Jayko et al. showed by using 29 synthetic peptides that some combinations of three or four peptides remarkably stimulated the lecithinase production when added to the synthetic medium. Among these peptides, glycyl-L-asparagine appeared to be most effective in lecithinase synthesis. The present authors tried to follow their experiments but were not able to confirm the toxin promoting effect of the synthetic peptides used by them. However, it was evident that fractions obtained from a protein digest were effective in the toxin production.

\section{Materials and Methods.}

Medium: Two types of synthetic medium were used as the basal medium. They were in principle similar to the chemically defined medium described by Boyd et al. (1948).* One of them was the modification by Jayko et al. (1959) and the other was that by the present authors. In the former medium (called SMJ), amounts of all amino acids were doubled, glucose was replaced by sucrose and glutamine was added in concentrations of 0.01-0.05 percent. In the latter (called SMT), fructose was used as carbohydrate, ascorbic acid was replaced by thioglycolic acid $(0.01 \%), \mathrm{Na}_{2} \mathrm{HPO}_{4}$ and $\mathrm{KH}_{2} \mathrm{PO}_{4}$ were used as the phosphate and glutamine was added in a concentration of 0.025 percent. Besides, a slight modification was given as regards vitamins and minerals (ref. Murata et al., 1958a).

A peptone medium was also used as the control in which a potent toxin is produced. It contains the following materials per $100 \mathrm{cc}$ : $5 \mathrm{~g}$ of Proteose Peptone No. 3 (Difco), $1 \mathrm{~g}$ of fructose, $0.92 \mathrm{~g}$ of $\mathrm{K}_{2} \mathrm{HPO}_{4}, 0.14 \mathrm{~g}$ of $\mathrm{KH}_{2} \mathrm{PO}_{4}, 20 \mathrm{mg}$ of $\mathrm{MgSO}_{4} \cdot 7 \mathrm{H}_{2} \mathrm{O}, 0.4 \mathrm{mg}$ of $\mathrm{MnCl}_{2} \cdot 4 \mathrm{H}_{2} \mathrm{O}, 0.6 \mathrm{mg}$ of $\mathrm{ZnSO}_{4} \cdot 7 \mathrm{H}_{2} \mathrm{O}, 0.7 \mathrm{mg}$ of $\mathrm{FeSO}_{4} \cdot 7 \mathrm{H}_{2} \mathrm{O}$ and thioglycolic acid in a concentration of 0.01 percent. $\mathrm{pH}$ was adjusted to 7.6 .

Synthetic peptides were obtained from Nutritional Biochemicals Corporation.

Preparation of fractions from proteose peptone: Dialysate of Proteose Peptone No. 3 (Difco) was concentrated in vacuo and fractionated with various ion exchange resins by batch method. A glass column of 250 by $35 \mathrm{~mm}$ filled with resin was employed except in the case of Amberlite CG 400 where a column of 600 by $33 \mathrm{~mm}$ was used. A procedure of preparing active fractions is described below.

One hundred and ten $\mathrm{cc}$ of the dialysate $(106 \mathrm{mg} / \mathrm{cc})$ was first passed through a column of Amberlite CG 120 (H-type). The column was washed with 21 of water until ninhydrin reaction became negative. The column was then eluted by passing through $2 \mathrm{~N}-\mathrm{NH}_{4} \mathrm{OH}$. The eluate and washings were combined and it was distilled in vacuo to dryness (Fraction 2). The fraction was dissolved in $140 \mathrm{cc}$ of distilled water and $120 \mathrm{cc}$ of this solution was passed through Amberlite CG 400 (OH-type), and the column was eluted by $2 \mathrm{~N}-\mathrm{CH}_{3} \mathrm{COOH}$. The mixture of eluate and washings was neutralized with $\mathrm{N}-\mathrm{NaOH}$ and then passed consecutively through three columns of

* Boyd's medium consists of : aminoacids, glucose, ascorbic acid, phosphate buffer $\left(\mathrm{K}_{2} \mathrm{HPO}_{4}\right.$ \& $\left.\mathrm{KH}_{2} \mathrm{PO}_{4}\right)$, several accessory growth factors and minerals. 
Amberlite CG 45 (OH-type), Amberlite CG 50 (H-type) and Amberlite CG 120 (H-type). The first column (Amberlite CG 45) was eluted by $2 \mathrm{~N}-\mathrm{CH}_{3} \mathrm{COOH}$ and the pool of eluate and washings was passed through CG 120 to remove acetic acid, and the latter resin was, in turn, eluted by $0.2 \mathrm{~N}-\mathrm{NH}_{4} \mathrm{OH}$. The pool of the eluate and washings was distilled in vacuo to dryness (Fraction 2-A, yield $1.668 \mathrm{~g}$ ). The second one (Amberlite CG 50) was eluted by $0.1 \mathrm{~N}-\mathrm{HCl}$ and the pool of the eluate and washings was passed through Amberlite $\mathrm{CG} 45$ to remove $\mathrm{HCl}$, and the pool of the filtrate and washings was concentrated in vacuo (Fraction 2-B, yield $1.618 \mathrm{~g}$ ). The last one (Amberlite CG 120) was eluted by $0.2 \mathrm{~N}-\mathrm{NH}_{4} \mathrm{OH}$ and the pool of the eluate and washings was distilled in vacuo to dryness (Fration 2-N, yield $3.6 \mathrm{~g}$ ).

Inoculum: A strain of Clostridium perfringens PB6K-N5 was grown in a seed medium consisting of the papain digest of beef supplemented with fructose (Murata et al. $1958 \mathrm{a}$ ). Cells from actively growing culture were washed twice with saline and resupended in saline of a half volume of the seed culture and $0.1 \mathrm{cc}$ was used to inoculate into $4 \mathrm{cc}$ of the medium.

Cultures: Experiments were carried out with tubes containing $4 \mathrm{cc}$ of the medium. All media were inoculated immediately after autoclaving. Anaerobic culture was carried out in an atmosphere of hydrogen at $37^{\circ} \mathrm{C}$.

Assay of alpha toxin: Toxin was titrated by the lecithovitellin method (Murata et al., 1956). When cell free supernatant was used, it was possible to titrate alpha toxin to $2 \mathrm{EU} / \mathrm{cc}$ (=6 $\mathrm{LD}_{50}$ by mice intravenous method).

Other methods: Nitrogen content was determined by micro-Kjeldahl method and phosphate by Allen's method. Tests for carbohydrate were carried out by Molish- and orcinol-reaction (Kabat \& Mayer, 1961).

\section{Results and Discussion.}

Table 1 shows the effect of several peptides on the toxin production. Contrary to our expectation, little amount of toxin was detected by the prescription recommended by Jayko et al. (1959), although the organism was able to grow abundantly in the medium. In the synthetic medium modified by the present authors, growth was rather poorer than in the Jayko et al. medium. However, alpha toxin was detected, though in a low titer. No favorable effect was observed by the addition of peptides. The experiment was repeated several times under anaerobic and aerobic conditions. Similar

Table 1. Effect of some peptides on the growth and toxin production

\begin{tabular}{lcc}
\hline \multicolumn{1}{c}{ Medium } & Growth O. D. $\$$ & Toxin EU/cc \\
\hline SMJ & 0.57 & 0 \\
SMJ +GA+GT+LGG & 0.61 & 0 \\
SMJ+GA+LGG+AA & 0.61 & 0 \\
SMT & 0.25 & 8 \\
SMT+GA+GT+LGG & 0.23 & 8 \\
SMT+GA+LGG+AA & 0.22 & 6 \\
Peptone medium & 0.95 & 142 \\
\hline
\end{tabular}

Incubated for 6 hours anaerobically.

Abbreviations

SMJ : Synthetic medium (Boyd) modified by Jayko et al. (1959).

SMT : Synthetic medium (Boyd) modified by the present authors.

AA : DL-alanyl-DL-alanine.

GA : glycyl-L-asparagine.

GT : glycyl-L-tryptophan.

LGG : L-leucyl-glycyl-glycine.

§. O. D. : Optical density at $660 \mathrm{~m} \mu$ with $1 \mathrm{~cm}$ light path by Coleman Junior Spectrophotometer. 
results were obtained by aerobic culture.

Then, the effect on the toxin production of Proteose Peptone No. 3 (Difco) and its derivatives was investigated by using the synthetic medium modified by us. As shown in Table 2, growth and toxin production were enhanced by three fractions of the peptone dialysate, $2 \mathrm{~B}, 2 \mathrm{~N}$ and $2 \mathrm{~A}$, the first two of these three fractions being very active, although the titer of toxin was inferior to that in the complex medium. However, it may be possible to state that such fraction(s) are necessary to promote the toxin production in the synthetic medium. The chemical nature of the active principles in these fractions have not yet been elucidated, but results of some chemical analyses are attached in Table 2. The three active fractions were negative by orcinol test and weakly positive (or doubtful) by Molish test. These results show that peptides and amino acids are main components of the active fractions. Since various amino acids and/or sugars (including glucosamine) were not able to stimulate the toxin production when added singly or in various combinations to the basal medium, it is most probable that some peptides may be responsible for the activity.

Table 2. Effect of Proteose Peptone and its derivatives on growth an tovin production

\begin{tabular}{|c|c|c|}
\hline Medium & Growth O. D. & Toxin EU/cc \\
\hline SMT & 0.15 & 3 \\
\hline SMT-Proteose Peptone $1 \mathrm{mg} / \mathrm{cc}$ & 0.50 & 50 \\
\hline $2.5 \mathrm{mg} / \mathrm{cc}$ & $0 \cdot 77$ & 100 \\
\hline \multirow{2}{*}{$\begin{array}{r}\text { SMT + Dialysate of Proteose Peptone } 1 \mathrm{mg} / \mathrm{cc} \\
2.5 \mathrm{mg} / \mathrm{cc}\end{array}$} & 0.55 & 38 \\
\hline & 0.82 & 77 \\
\hline $\mathrm{SMT}+$ Fraction $2,1 \mathrm{mg} / \mathrm{cc}$ & 0.22 & 18 \\
\hline $\mathrm{SMT}+$ Fraction $2 \mathrm{~B}, 1 \mathrm{mg} / \mathrm{cc}$ & 0.34 & 30 \\
\hline $\mathrm{SMT}+$ Fraction $2 \mathrm{~N}, 1 \mathrm{mg} / \mathrm{cc}$ & 0.53 & 39 \\
\hline $\mathrm{SMT}+$ Fraction $2 \mathrm{~A}, 1 \mathrm{mg} / \mathrm{cc}$ & 0.21 & 16 \\
\hline Peptone medium & 0.95 & 200 \\
\hline
\end{tabular}

Incubated for 6 hours aerobically at $35^{\circ} \mathrm{C}$ in a water bath.

Chemical nature of the fractions of the peptone:

$\begin{array}{lll} & \mathrm{N} \% & \mathrm{P} \% \\ \text { Dialysate } & 15.2 & 0.60 \\ \text { Fr. 2 } & 13.6 & 0.55 \\ 2 \mathrm{~B} & 13.4 & 0 \\ \text { 2 N } & 12.0 & 0.51 \\ \text { 2 A } & 12.7 & 0.10\end{array}$

The reason why we obtained results different from those of Jayko et al. is not understandable. We followed their experiment exactly according to their description except that the strain was different. Therefore, it is plausible that the discrepancy between their and our results may be due to the difference in the strain used, although both strains are the substrains of $\mathrm{Cl}$. perfringens $\mathrm{PB} 6 \mathrm{~K}$.

\section{Summary.}

Some synthetic peptides, reportedly active in toxin synthesis, failed to promote the 
alpha toxin production by a strain of $\mathrm{Cl}$. perfringens $\mathrm{PB} 6 \mathrm{~K}$. However, it is evident that certain fractions derived from a protein digest supported the production of a potent toxin.

\section{REFERENCES}

Boyd, M. J., Logan, M. A. \& Tytell, A. A. (1948): The growth requirements of Clostridium perfringens (welchii) BP6K. J. Biol. Chem., 174, 1013-1025.

JAYKo, L. G. \& LichSTEIN, H. C. (1959): Nutritional factors concerned with growth and lecithinase production by Clostridium perfringens. J. Infect. Dis., 104, 142-151.

KABAT, E. A. \& MAYer, M. M. (1961): Experimental Immunochemistry, 2nd Ed., p. 526, C. C. Thomas, Springfield.

Murata, R., Yamada, T. \& Kameyama, S. (1956) : Production of alpha toxin of Clostridium perfringens I. Jap. J. M. Sc. \& Biol., 9, 81-91.

Murata, R., Yamada, T., Kameyama, S. \& WadA, E. (1958) : Production of alpha toxin of Clostridium perfringens II. Jap. J. M. Sc. Biol., 11, 415-425.

Murata, R., Yamada, T. \& Kameyama, S. (1958): Production of alpha toxin of Clostridium perfringens III. Jap. J. M. Sc. \& Biol., 11, 427-442.

Department of Bacteriology II, National Institute of Health, Tokyo

MASAKO TSUKAMOTO

AKIO YAMAMOTO

RYOSUKE MURATA

Received: June 24th, 1963

塚本雅子・山本昭夫・村田良介（国立予防衛生研究所細菌第二部） 